\title{
Effect of Nitrogen Fertilizer and Its Application Efficiency on Two Local Sorghum Cultivars Sorghum bicolor L. Moench
}

\author{
Abdulla A. Mohamed Muflahi ${ }^{1} \&$ Ahmed Saleh Basuaid $^{2}$ \\ ${ }^{1}$ Soil and Irrigation Section, El-Kod Agricultural Research Station (AREA), Republic of Yemen \\ ${ }^{2}$ Nasser Faculty of Agriculture Science, Aden University, Republic of Yemen \\ Correspondence: Abdulla A. Mohamed Muflahi, Soil and Irrigation Section, El-Kod Agricultural Research \\ Station (AREA), Republic of Yemen. E-mail: alqudime@hotmail.com
}

Received: January 9, 2017

Accepted: February 28, 2017

Online Published: March 15, 2017

doi:10.5539/jas.v9n4p236

URL: https://doi.org/10.5539/jas.v9n4p236

\begin{abstract}
A field experiment was carried out at El-Kod Agricultural Research Station, Abyan Delta, Abyan Governorate during the seasons 2014 and 2015 in soil sandy silt to assess four levels of nitrogen fertilizers $(0,55,110$ and 165 $\mathrm{kg} \mathrm{N} / \mathrm{ha}$ ) utilizing urea fertilizer $(46 \% \mathrm{~N})$ on some crop characteristics and efficiency of nitrogen application on two local cultivars of sorghum (Sorghum bicolor L. Moench). Split plot design was applied in four replicates. Fertilizer levels were distributed in main plots whereas, the cultivars in subplots. The results revealed significant differences between cultivars Benny and Saif in all characteristics during the two seasons. Cultivar Benny was significantly superior to cultivar Saif in all crop characteristics, except the length of spike which was significantly superior in Saif cultivar compared to cultivar Benny in both seasons. The increase in nitrogen level led to significant increase in all parameters of crop growth under study in both seasons, where the highest dose of nitrogen (165 kg N/ha) gave highest grain yield (3013 and $3201 \mathrm{~kg} / \mathrm{ha}$ ) in both seasons respectively, while the efficiency of nitrogen utilization declined with increased level of nitrogen application and highest value in nitrogen efficiency $(12.78 \mathrm{~kg}$ grain $/ \mathrm{kg} \mathrm{N})$. The interaction between cultivars and nitrogen fertilizer showed significant differences in terms of all studied parameters during both seasons. The cultivar Benny responded to high level of nitrogen (165 kg N/ha) and gave high grain yield (3640 and $3305 \mathrm{~kg} / \mathrm{ha}$ ) in both seasons respectively. The results yielded significant effect for efficiency of nitrogen application on grain yield between the cultivars, the levels of fertilizers and their interaction in the first season whereas, no significant differences were detected in the second season.
\end{abstract}

Keywords: nitrogen fertilizer, cultivars, growth, sorghum grain crop

\section{Introduction}

Sorghum (Sorghum bicolor L. Moench) is a major crop which belongs to the family Gramineae and has several characteristics which distinguishes it from other crops such as its resistance to salt, drought and high temperature (Novoa \& Naik, 1978; Ottman \& Olson, 2009; Novoa \& Loomis, 1981) apart from its use particularly, fodder for animal and its grains are utilized for human consumption in the world (Armah-Agyeman et al., 2002). It is also used in African countries and mixed its flour with wheat in proportion 50\%. Its grain contains $10 \%$ protein and $67 \%$ carbohydrate and is rich in vitamin B. It is characterized as a source of organic fuel by application of starch, sugar and plant organic products (Henzell, 2007).

Global acreage under sorghum according to statistics for 2014 reaches 42,120,446 ha and yielded nearly 61,384,559 metric ton, with average yield being 1.4574 metric ton/ha. Area harvested in Arab countries according to 2014 statistics reached 1,192,476 ha and produced nearly 8044284 metric ton and average yield being 6.746 metric ton/ha (FAO, 2014). Sorghum in Yemen is a major cereal crop and occupies priority in terms of area which in 2014 reached 416,637 ha and yielded 340754 metric ton grain, with average yield being 0.8179 metric ton/ha (FAO, 2014). It is a main cereal crop for human use and has increasing demand due to increase in population (Alhibshi, 2000).

Nitrogen nutrition is not the sole factor which leads to increase in yield of this crop, but it requires screening of introduced and breeded cultivars in Yemen which varies in its response to nitrogen application and its efficiency to cope with environmental factors and enhance and enhance photosynthesis to increase the yield qualitatively 
and quantitatively. Several studies indicated variation in sorghum cultivars in terms of crop contents, grains and harvest index (Gardner et al., 1994; Prinar \& Stewart, 1991; Salama, 2008; AlSuleimani, 2009). Several studies have been conducted on effect of nitrogen on sorghum crop and positive results were recorded on increase in grain per spike, weight of grain and yield of crop per unit area (Kaye et al., 2007; Conly et al., 2005; Buah \& Mwinkaara, 2009; Lehman et al., 1999; Yasser, 2011). Grimes and Music (1960) reported increase in nitrogen rate in sorghum gave increase in yield whereas, reduction in number of days from planting to flowering by $50 \%$ were observed in high nitrogen rate (Myers, 1978). Escasinas et al. (1981) reported that increase in nitrogen rate led to significant increase in length of spike, number grains per spike and yield. Increase in nitrogen rate. Increase in nitrogen rate from 30-200 kg N/ha led to increase in grain yield and $200 \mathrm{~kg} \mathrm{~N} / \mathrm{ha}$ produced yield 2.3 metric ton/ha and in the absence of nitrogen, the yield dropped to 1.3 metric ton/ha. Al Rawi (2005) confirmed that highest grain weight and grain yield were observed at $180 \mathrm{~kg} \mathrm{~N} / \mathrm{ha}$. Sifola et al. (2002) indicated that nitrogen increases the number of grains in flower particularly, during application at $150 \mathrm{kgN} / \mathrm{ha}$, apart from accumulation of dry matter during grain filling in the spike.

The efficiency of nitrogen application is a main criteria for accurate application of nitrogen, inorder to determine the variation in cultivars for efficient utilization and during different levels of application to reduce the contamination and cost of nitrogen fertilizer (Gardner et al., 1994)

Present study is aimed to investigate the response of two local cultivars of sorghum (cv. Benny and Saif) to four levels of nitrogen and its effect on growth, crop components to determine promising cultivar and ideal nitrogen level which leads to high yield from unit area.

\section{Materials and Methods}

Two experiments were conducted at El-Kod Agricultural Research Station, Abyan Governorate (latitude $13^{\circ} 03^{\prime} \mathrm{N}$, longitude $45^{\circ} 22^{\prime} \mathrm{E}$, altitude $15 \mathrm{~m}$ ) during the seasons 2014 and 2015 to study the effect of different doses of nitrogen fertilizer on some characteristics of growth and crop components in two local cultivars of sorghum (cv. Benny and Saif). The site is characterized by hot and arid climate with average annual potential evapotranspiration in is $1795 \mathrm{~mm}$ per year. Mean daily sunshine duration is over $8.8 \mathrm{~h}$, mean annual air humidity is $72 \%$ and mean annual temperature is $28.1{ }^{\circ} \mathrm{C}$ (Table1).

Table 1. Climatic data (1971-2008) of El-Kod weather station

\begin{tabular}{llllllllll}
\hline Month & Min Temp & Max Temp & Mean Temp & Humidity & Rain & Wind & Sun & Rad & ETo \\
\hline & ${ }^{\circ} \mathrm{C}$ & ${ }^{\circ} \mathrm{C}$ & ${ }^{\circ} \mathrm{C}$ & $\%$ & $\mathrm{~mm}$ & $\mathrm{~km} / \mathrm{day}$ & hours & $\mathrm{MJ} / \mathrm{m}^{2} / \mathrm{day}$ & $\mathrm{mm} / \mathrm{month}$ \\
Jan. & 21.6 & 28.3 & 25.0 & 72.0 & 3.2 & 154.0 & 8.0 & 18.4 & 120.3 \\
Feb. & 21.3 & 28.7 & 25.0 & 73.0 & 6.3 & 168.0 & 8.6 & 20.7 & 121.2 \\
Mar. & 21.2 & 30.2 & 25.7 & 73.0 & 4.0 & 174.0 & 8.5 & 22.0 & 146.8 \\
Apr. & 23.0 & 32.3 & 27.7 & 72.0 & 2.6 & 154.0 & 9.0 & 23.4 & 155.5 \\
May & 25.7 & 34.7 & 30.2 & 73.0 & 1.8 & 136.0 & 10.2 & 25.0 & 176.7 \\
Jun. & 27.4 & 35.7 & 31.6 & 70.0 & 0.7 & 138.0 & 8.7 & 22.4 & 166.3 \\
Jul. & 27.7 & 35.0 & 31.4 & 70.0 & 1.2 & 156.0 & 8.0 & 21.4 & 169.2 \\
Aug. & 26.7 & 35.0 & 30.9 & 69.0 & 2.2 & 151.0 & 8.5 & 22.4 & 173.2 \\
Sep. & 26.1 & 35.2 & 30.7 & 72.0 & 3.5 & 126.0 & 8.6 & 22.2 & 161.0 \\
Oct. & 22.6 & 32.9 & 27.8 & 72.0 & 6.0 & 127.0 & 9.5 & 22.3 & 154.5 \\
Nov. & 20.2 & 30.7 & 25.5 & 71.0 & 0.2 & 119.0 & 10.0 & 21.4 & 130.6 \\
Dec. & 21.0 & 29.2 & 25.1 & 71.0 & 1.3 & 135.0 & 8.6 & 18.7 & 119.7 \\
Aver. & 23.7 & 32.3 & 28.1 & 72.0 & 33.0 & 145.0 & 8.8 & 21.7 & 1795.0 \\
\hline
\end{tabular}

Each trial consisted of four doses of nitrogen fertilizer $(0,55,110$ and $165 \mathrm{~kg} \mathrm{~N} / \mathrm{ha})$ with two sorghum cultivars (cv. Benny and Saif) and arranged in split plot design in four replicates. The nitrogen fertilizer treatments were randomly distributed in main plots and cultivars were randomly distributed in subplots. Each treatment was replicated four times. Each experimental unit consisted of 6 rows with spacing $50 \mathrm{~cm}$ between rows and $20 \mathrm{~cm}$ between plants. The area of each experimental unit was $6 \mathrm{~m}^{2}(3 \times 2) \mathrm{m}$.

Phosphate fertilizer at the rate of $120 \mathrm{~kg} / \mathrm{ha}$ (Calcium triphosphate $46 \%$ ) was added during land preparation and leveling. During the first season, sorghum was planted on 10/07/2014 and in the second season on 15/07/2015 in soil sandy silt with $\mathrm{pH} 8.25$ and 8.26 and contained 0.56 and 0.58 organic matter, $0.03 \%$ and $0.35 \%$ nitrogen and 
available phosphor 8.6 and $10.0 \mathrm{ppm}$ and electrical conductivity (EC) 0.88 and $1.15 \mathrm{mmhos} / \mathrm{cm}$ for soil depth $0-30 \mathrm{~cm}$. Seeds of sorghum cultivars were sown in rows $50 \mathrm{~cm}$ apart and spacing between plants $20 \mathrm{~cm}$. Each experimental unit contained 6 rows. Nitrogen fertilizer was added in split, the first dose during planting, the second dose during thinning and the third dose during flowering in proportion 2:1:1 respectively. Thinning was done after three weeks from planting; one plant was left in each hole. All cultural practices were exercised according to the recommendations of El-Kod Agricultural Research Station Cultivar Saif was harvested on 11/10/2014 and cultivar Benny on 1/11/2014 for the first season and during the second season, cultivar Saif was harvested on 20/10/2015 and cultivar Benny on 9/11/2015. After completion of flowering, ten plants were randomly labeled in each experimental plot for data collection on crop components (length of spike, number of grains/spike, weight of 1000 grains yield and efficiency of plant to respond to nitrogen $\mathrm{kg}$ grains $/ \mathrm{kg} \mathrm{N}$ ). The yield of grains and dry matter were calculated from each experimental plot.

The efficiency of nitrogen utilization for grain production was determined according to (Buah \& Mwinkaara, 2009):

$$
N U_{2}=\left(G Y_{x}-G Y_{0}\right) / x
$$

Where,

$\mathrm{NU}_{2}$ : The efficiency of nitrogen utilization for production of grains $(\mathrm{kg}$ grain $/ \mathrm{kg} \mathrm{N}) ; G Y_{x}$ : The yield of grains at nitrogen level $\mathrm{kg} \mathrm{N} / \mathrm{ha} ; G Y_{0}$ : The yield of grains (control) $(\mathrm{kg} / \mathrm{ha}) ; X$ : The level of nitrogen applied $(\mathrm{kg} \mathrm{N} / \mathrm{ha})$.

The results were analyzed statistically according to the design reported by Snddecor and Cochran (1989) and utilizing Genstat program. Mean values were compared at $\mathrm{P}=0.05$ (Al Rawi \& Khalafallah, 1980).

\section{Results and Discussion}

\subsection{Crop Components}

The results revealed significant differences between sorghum cultivars (cv. Benny and Saif) during the season 2014 and 2015 in all crop characteristics and components under study (Length of spike, number of grains/spike, weight of 1000 grains and grain yield). Cultivar Benny was significantly superior to Saif in parameters such as number of grains/spike and reached 904 and 899 grains with the rate of increase $28.8 \%$ and $44.6 \%$, Weight of 1000 grains being 30.9 and $32.115 \mathrm{~g}$ with increase being $9.8 \%$ and $7.5 \%$ and yield of dry matter 2906 and 2824 $\mathrm{kg} / \mathrm{ha}$ for seasons 2014 and 2015 respectively. Cultivar Saif was significantly superior to Benny in length of spike and reached 30.07 and $21.45 \mathrm{~cm}$ with the rate of increase $25.7 \%$ and $20.2 \%$ for the two seasons respectively. These results are confirmed by Al A'ani (2010), Al Dahri and Saleh (2010), Gardner et al. (1994), Al Kubaisi (2001), Guar et al. (2008), Sadras and Egli (2008), Yang et al. (2009), and Yasser (2011). The results indicated an increase in all crop components under study with increase in nitrogen level application. The highest dose of nitrogen application gave high value in all crop components during the seasons 2014 and 2015. The length of spike was 30.15 and $21.42 \mathrm{~cm}$, number of grains/spike was 986 and 1058, weight of 1000 grains reached 30.278 and $34.75 \mathrm{~g}$ and crop yield 3013 and $3201 \mathrm{~kg} / \mathrm{ha}$ respectively. The highest nitrogen dose $(165 \mathrm{~kg}$ $\mathrm{N} / \mathrm{ha}$ ) was superior to the two treatments (control and $55 \mathrm{~kg} \mathrm{~N} / \mathrm{ha}$ ) in all crop components. The rate of increase being 94.1 and $25.3 \%$ for length of spike, 7.1 and 2.9 for weight of 1000 grains and 74.0 and $26.1 \%$ for crop yield respectively. Significant increase was recorded when $(165 \mathrm{~kg} \mathrm{~N} / \mathrm{ha})$ is compared with nitrogen dose (110 $\mathrm{kg} \mathrm{N} / \mathrm{ha}$ ) in length of spike and crop yield. The rate of increase was $11.2 \%$ and $24.6 \%$ for the two parameters respectively, whereas, no significant increase was noted in other parameters during the season 2014. In the season 2015, the high dose of nitrogen (165 kg N/ha) was superior to all doses (treatments) (control, 55, and 110 $\mathrm{kg} \mathrm{N} / \mathrm{ha}$ ) in all crop components. The rate of increase for length of spike was $19.2 \%, 12.3 \%, 6.6 \%$. The number of grains/spike was $102.3 \%, 53.2 \%, 20.8 \%$, the weight of 1000 grains $19.8 \%, 17.3 \%, 13.5 \%$ and crop yield $124.0 \%, 54.6 \%, 18.75 \%$ respectively. These results are in agreement with Al Kubaisi (2001), Al Salmani (2009), Conly et al. (2005), A'atia et al. (2001), Buah and Winkar (2009), Gardner et al. (1994), Kaye et al. (2007), Salama (2008), Gular (2008), Wright and Catchpoole (1985), and Yang et al. (2009).

The interaction between cultivars and fertilizer revealed significant effect in all crop components for both seasons 2014 and 2015. It is observed from Table 2 that there is increase in value of different crop components for both cultivars with increase in nitrogen level. High nitrogen level (165 kg N/ha) applied to cultivar Benny gave high value in number of grains/spike 1075, 1170 grains, weight of 1000 grains $31.525,36.5 \mathrm{~g}$ and grain yield $3640,3305 \mathrm{~kg} / \mathrm{ha}$, whereas, cultivar Saif showed low value in control (no fertilizer) in number of grains/spike 505,371 grains, weight of 1000 grains $26.775,28.0 \mathrm{~g}$, yield of grain 1404,990 kg/ha for two seasons respectively. This significance in interaction is attributed to variation in cultivars and their genotype, apart from different characteristics in these cultivars such as adaptation to the environment in agricultural region. The 
increase in yield and its components as a result of nitrogen application is due to plant growth, efficiency of photosynthesis and cell contents in protein which leads to increased activity in metabolic process leading to cell enlargement and its nutritional content. These findings agree with Amal (1998), Gardner et al. (1994), Heiniger et al. (1997), Wright and Catchpoole (1985).

\subsection{Plant Efficiency to Utilize Nitrogen}

Significant differences are observed between the cultivars (cv. Benny and Saif) in efficient utilization of nitrogen for grain production during the season 2014, whereas, no significant differences were detected during the season 2015. Cultivar Benny showed high efficiency being $8.28 \mathrm{~kg}$ grains $/ \mathrm{kg} \mathrm{N}$ compared to cv. Saif which gave low efficiency $5.6 \mathrm{~kg}$ grain $/ \mathrm{kg} \mathrm{N}$. This variation in characteristics is attributed to cultivar genotype which reflected on plant capability to absorb nitrogen from the soil. These results are confirmed by Crawford et al. (2009).

Significant differences were detected between levels of nitrogen applied and efficiency of nitrogen utilization for grain production during the first season and no significant differences were found in the second season. In the first season, nitrogen level $55 \mathrm{~kg} \mathrm{~N} /$ ha showed high efficiency being $12.78 \mathrm{~kg}$ grain $/ \mathrm{kg} \mathrm{N}$ and was superior to levels 110 and $165 \mathrm{~kg} \mathrm{~N} / \mathrm{ha}$ which showed low efficiency being 8.5 and $6.48 \mathrm{~kg}$ grain $/ \mathrm{kg} \mathrm{N}$. It is also observed that efficiency of nitrogen utilization declined with increased level of nitrogen application. This is due to low crop response with higher level of nitrogen application (Gawad, 1988). These results are in agreement with Akdeniz et al. (2006), and Buah and Mwinkaara (2009), who reported low efficiency of nitrogen utilization for grain production with increased levels of nitrogen application. It is observed from Table 2 that significant differences were detected for these parameters in interaction between cultivars and levels of nitrogen applied in the first and second seasons. Cultivar Benny showed high efficiency being $14.65,12.27 \mathrm{~kg}$ grain $/ \mathrm{kg} \mathrm{N}$ at $55 \mathrm{~kg}$ $\mathrm{N} / \mathrm{ha}$, whereas, cultivar Saif gave low efficiency being 5.36, $8.71 \mathrm{~kg}$ grain $/ \mathrm{kg} \mathrm{N}$ for the nitrogen level $165 \mathrm{~kg}$ $\mathrm{N} / \mathrm{ha}$ for both seasons respectively. These results are confirmed with the findings reported by Bernal et al. (2001).

Table 2. The effect of nitrogen fertilizer on crop components of two local cultivars of sorghum for season 2014 and 2015

\begin{tabular}{|c|c|c|c|c|c|c|c|c|c|c|c|}
\hline \multirow[b]{2}{*}{ Treatments } & \multirow[b]{2}{*}{ Parameters } & \multicolumn{5}{|c|}{ Season 2014} & \multicolumn{5}{|c|}{ Season 2015} \\
\hline & & $\begin{array}{l}\text { Length } \\
\text { of spike } \\
\text { (cm) }\end{array}$ & $\begin{array}{l}\text { No of } \\
\text { grains/ } \\
\text { spike }\end{array}$ & $\begin{array}{l}\text { Wt. of } \\
1000 \\
\text { grains (g) }\end{array}$ & $\begin{array}{l}\text { Yield } \\
\text { of grain } \\
\text { (kg/ha) }\end{array}$ & $\begin{array}{l}\text { Efficiency of } \\
\text { N utilization } \\
\text { (grain/kg N) }\end{array}$ & $\begin{array}{l}\text { Length } \\
\text { of spike } \\
\text { (cm) }\end{array}$ & $\begin{array}{l}\text { No of } \\
\text { grain/ } \\
\text { spike }\end{array}$ & $\begin{array}{l}\text { Wt. of } \\
1000 \\
\text { grains (g) }\end{array}$ & $\begin{array}{l}\text { Yild of } \\
\text { grain } \\
\text { (kg/ha) }\end{array}$ & $\begin{array}{l}\text { Efficiency of } \\
\text { N utilization } \\
\text { (grain/kg N) }\end{array}$ \\
\hline \multirow{3}{*}{ Cultivar (A) } & Benny (A1) & 23.92 & 899 & 30.90 & 2906 & 8.28 & 17.84 & 904 & 32.125 & 2824 & 8.73 \\
\hline & Saif (A2) & 30.07 & 698 & 28.15 & 2069 & 5.60 & 21.45 & 625 & 29.875 & 1841 & 7.92 \\
\hline & $\mathrm{Lsd}=0.05$ & 1.325 & 97.1 & 0.3049 & 293.1 & 1.519 & 1.180 & 52.3 & 0.3975 & 151.7 & - \\
\hline \multirow{5}{*}{$\begin{array}{l}\text { Nitrogen Levels } \\
\text { (kg/ha) (B) }\end{array}$} & 0 & 24.67 & 508 & 28.287 & 1732 & 0.00 & 17,97 & 508 & 29.00 & 1429 & 0.00 \\
\hline & 55 & 26.04 & 787 & 29.425 & 2390 & 12.78 & 19.07 & 671 & 29.625 & 2071 & 11,68 \\
\hline & 110 & 27.11 & 912 & 30.100 & 2418 & 8.50 & 20.10 & 851 & 30.625 & 2629 & 10.89 \\
\hline & 165 & 30.15 & 986 & 30.287 & 3013 & 6.48 & 21.42 & 1028 & 34.750 & 3201 & 10.74 \\
\hline & $\mathrm{Lsd}=0.05$ & 1.613 & 150.4 & 0.2336 & 179.2 & 1.979 & 0.569 & 125.2 & 0.6826 & 315.6 & NS \\
\hline \multirow[t]{4}{*}{$\mathrm{B}^{*} \mathrm{~A} 1$} & 0 & 22.05 & 512 & 29.8 & 2361 & 0.00 & 16.55 & 644 & 30.00 & 1867 & 0.00 \\
\hline & 55 & 22.94 & 954 & 30.875 & 2557 & 14.65 & 17.45 & 766 & 30.50 & 2478 & 13.07 \\
\hline & 110 & 25.16 & 1054 & 31.400 & 3167 & 10.87 & 18.30 & 1035 & 31.50 & 2645 & 11.09 \\
\hline & 165 & 25.52 & 1075 & 31.525 & 3640 & 7.60 & 19.05 & 1170 & 36.50 & 3305 & 10.77 \\
\hline \multirow[t]{5}{*}{$B * A 2$} & 0 & 27.29 & 505 & 26.775 & 1404 & 0.00 & 19.40 & 371 & 28.00 & 990 & 0.00 \\
\hline & 55 & 28.71 & 620 & 27.975 & 1862 & 10.92 & 20.70 & 577 & 28.750 & 1665 & 12.27 \\
\hline & 110 & 29.15 & 750 & 28.8 & 2077 & 6.12 & 21.90 & 667 & 29.75 & 1935 & 10.77 \\
\hline & 165 & 35.14 & 918 & 29.05 & 2338 & 5.36 & 23.80 & 886 & 33.00 & 2758 & 8.71 \\
\hline & $\mathrm{Lsd}=0.05$ & 2.324 & 191.0 & 0.4696 & 437.1 & 2.741 & 1.723 & 138.1 & 0.8288 & 360.2 & 3.32 \\
\hline
\end{tabular}

\section{Conclusions}

The increase in nitrogen level led to significant increase in all parameters of crop growth under study in both seasons, where the highest dose of nitrogen $(165 \mathrm{~kg} \mathrm{~N} / \mathrm{ha})$ gave highest grain yield $(3013$ and $3201 \mathrm{~kg} / \mathrm{ha})$ in both seasons respectively, while the efficiency of nitrogen utilization declined with increased level of nitrogen 
application. The interaction between cultivars and nitrogen fertilizer showed significant differences in terms of all studied parameters during both seasons. The cultivar Benny responded to high level of nitrogen ( $165 \mathrm{~kg} \mathrm{~N} / \mathrm{ha})$ and gave high grain yield (3640 and $3305 \mathrm{~kg} / \mathrm{ha}$ ) in both seasons respectively.

\section{Acknowledgements}

The authors express thanks and gratitude to all who contributed in implementation and success of this research particularly, Water Livelihood Initiative project (WLI) led by ICARDA and sponsored by USAID for the financial support towards this research.

\section{References}

A'atia, H. G., Khader, A. G., \& Al Shaligi, D. (2001). Effect of plant density and nitrogen fertilizer on growth and yield of sorghum. Iraqi Journal of Agricultural Science, 2(5), 53.

Akdeniz, I. Y., Bozkurt, M. A., \& Kesin, B. (2006). The effects of sewage sludge and nitrogen application on grain sorghum grown (Sorghum vulgare L.) in Van-Turkey. Polish Journal of Environmental Studies, 15(1), 19-26.

Al Dahri, A., \& Saleh, M. (2010). Effects of level of nitrogen fertilizer and growth and yield of three cultivars of sorghum (Sorghum bicolor L. Moench) (MSc. Thesis, Faculty of Agriculture, Al Anbar University, Iraq).

Al Kubaisi, M. I. (2001). Time and methods of nitrogen fertilizer application on growth and yield of two sorghum cultivars (MSc. Thesis, Faculty of Agriculture, Baghdad University).

Al Rawi, K. M., \& Khalafallah, A. A. (1980). Design and analysis of agricultural experiments (Al Mosul University, Iraq, p. 488).

Al Rawi, O. H. I. (2005). Response of three sorghum cultivars to spacings (MSc. Thesis, Faculty of Agriculture, AlAnbar University, Iraq).

Al Salmani, S. A. A. (2009). Analysis of coefficient of correlation in sorghum on plant density (MSc. Thesis, Faculty of Agriculture, Al Anbar University, Iraq).

Alhibshi, M. (2000). Causes of nutritional gap in Yemen. Sabaa Economic Journal, 16, 30-31.

Amal, G. A. (1998). Physiological studies on production of grain sorghum (Ph.D Thesis, Faculty of Agriculture, Cairo, p. 198).

Amal, G. A., Nabila, M., \& Hassanin, M. S. (2007). Response of grain sorghum to effect of nitrogen sources. Research Journal of Agriculture and Biological Science.

Armah-Agyeman, G., Loiland, J., Karow, R., Payne, W. A., Trostle, C., \& Bean, B. (2002). Grain Sorghum (pp. 1-5). Oregon State University.

Bernal, J. H., Navas, G. E., \& Clark, R. B. (2001). Sorghum nitrogen use efficiency in Columbia. Plant Nutrition, Food Security and Sustainability of Agro-Ecosystems, 66-67.

Buah, S. S. J., \& Mwinkaara, S. (2009). Response of sorghumto nitrogen fertilizer and plant density in the Guinea Savana zone. Journal of Agronomy, 8(4), 124-130. https://doi.org/10.3923/ja.2009.124.130

Conly, S. P., Stevens, W. G., \& Dunn, D. D. (2005). Grain sorghum response to row spacing, plant density planter skip online. Crop Management, 10, 1094. https://doi.org/10.1094/CM-2005-0718-01-RS

Crawford, T. W., Eskridge, K. M., Wang, C. G., \& Maranville, J. W. (2009). Multi-compartmental modeling of nitrogen translocation in sorghums differing in nitrogen use efficiency. Journal of Plant Nutrition, 32(1-3), 335-349. https://doi.org/10.1080/01904160802638186

Escasinas, R. O., Escalada, R. G., \& Trenuela, R. M. (1981). Effect of different population densities and nitrogen levels on the yield and yield components of sorghum. Annuals of Tropical Research, 3(4), 258-265.

FAO. (2014). Statistical year book.

Gardner, J. C., Maranville, J. W., \& Paparozzi, E. T. (1994). Nitrogen use efficiency among diverse sorghum cultivars. Crop Science, 34, 728-733. https://doi.org/10.2135/cropsci1994.0011183X003400030023x

Gawad, K. S., Hamza, M. A., \& A'aloosh, K. H. (1988). Soil fertility and application of fertilizers (p. 391). Ministry of Higher Education and Research, Technical Agricultural Institute, Baghdad, Iraq.

Grimes, D. W., \& Music, J. T. (1960). Effect of plant spacing, fertility and irrigation Managements on grain sorghum production. Agronomy Journal, 52, 647-733. https://doi.org/10.2134/agronj1960.000219620052 00110011x 
Guler, M., Gul, I., Yilmas, S., Emeklier, H. Y., \& Akdogan, G. (2008). Nitrogen and plant density effect on sorghum. Journal of Sgronomy, 7(3), 220-228. https://doi.org/10.3923/ja.2008.220.228

Heiniger, R. W., Vanderlip, R. L., Welch, S. M., \& Muchow, R. C. (1997). Developing guidelines for replanting grain sorghum II improved methods of simulating caryopsis weight and tiller number. Agronomy Journal, 89, 84-92. https://doi.org/10.2134/agronj1997.00021962008900010013x

Henzell, B. (2007). Strategy for the global Ex situ conservation of sorghum genetic Diversity. GRDS, Australia.

Kaye, N. M., Mason, S. C., Jackson, D. S., \& Galusha, T. D. (2007). Crop rotation and soil Amendment alerts sorghum grain quality. Crop Science, 47, 722-729. https://doi.org/10.2135/cropsci2006.05.0346

Lehmann, J., Feilner, T., Gebaruer, G., \& Zech, W. (1999). Nitrogen uptake of sorghum from Tree mulch and mineral fertilizer under high leaching condition estimated by nitrogen-15 enrichment. Bio. Fert. Soils, 90-95. https://doi.org/10.1007/s003740050592

Myers, R. J. K. (1978). Nitrogen and phosphorous nutrition of dryland grain sorghum at Katrerine, Northern territory: Effect of rate of nitrogen fertilizer. Australian Journal of Agriculture and Animal Husbandry, 18, 554-563. https://doi.org/10.1071/EA9780554

Naik, L. B. (1978). Effect of three levels of nitrogen and low stage of harvesting earhead on the development of top side shoots and yield of (sh-5, GS-3541) and SB-4611 sorghum genotype. FCA, 33(2), 1263.

Novoa, R., \& Loomis, R. S. (1981). Nitrogen and plant production. Plant and Soil, 58, 177-204. https://doi.org/10.1007/BF02180053

Ottman, M. J., \& Olson, M. W. (2009). Growing grain sorghum in Arizona (p. 3). University of Arizona, College of Agriculture and Life Science, Tucson, Arizona, USA.

Prinar, S. S., \& Stewart, B. A. (1991). Sorghum harvest index in relation to plant size, environment and cultivar. Agronomy Journal, 83(3), 603-608. https://doi.org/10.2134/agronj1991.00021962008300030020x

Sadras, V. O., \& Egli, D. S. (2008). Seed size variation in grain crop: Allometric relationship between rate and duration of seed growth. Crop Science, 48, 409-416. https://doi.org/10.2135/cropsci2007.05.0292

Salama, M. A. A. (2008). Response of sorghum (Sorghum bicolor L. Moench) to nitrogen Fertilizer. Iraqi Journal for Desert Studies, 1(1), 11-17.

Sifola, M. I., Morl, M., \& Xeccon, P. (2002). Biomass and nitrogen partitioning in sorghum (Sorghum vulgare L.) as affected by nitrogen fertilization. Italian Journal of Agronomy, 1(2), 115-121.

Sneddcor, G. W., \& Cochran, W. G. (1989). Statistical methods (8th ed.). Iowa State University Press, Ames, Iowa, USA.

Wright, G. S., \& Catchpoole, V. R. (1985). Rate of urea nitrogen applied at planting to grain sorghum growth under sprikler and furrow irrigation. Aust. Jour. Agric. Res., 36, 677-684. https://doi.org/10.1071/ AR9850677

Yang, Z., Oosterom, E. J. V., Jordon, D. R., \& Hammer, G. L. (2009). Preanthesis ovary development determines genotypic differences in potential kernel weight in sorghum. J. of Exp. Botany, 60(4), 1399-1408. https://doi.org/10.1093/jxb/erp019

Yasser, M. A. (2011). The effect of nitrogen fertilizer on growth and yield of two sorghum Cultivars under Delta Tuban condition. Yemeni Journal of Aggricultural Research, 32.

\section{Copyrights}

Copyright for this article is retained by the author(s), with first publication rights granted to the journal.

This is an open-access article distributed under the terms and conditions of the Creative Commons Attribution license (http://creativecommons.org/licenses/by/4.0/). 